\title{
Expression of Antioxidant Enzymes and Changes in Some Physiological Parameters Following the Short-term Heavy Metal Application in Wheat
}

\author{
HULYA YILDIR ${ }^{1}$, FILIZ SANAL ${ }^{2 *}$ (iDhtps://orcid.org/0000-0002-5830-4811) \\ ${ }^{1}$ Department of Biology, Faculty of Sciences, Trakya University, Edirne, Turkey \\ ${ }^{2}$ Department of Biology, Faculty of Sciences, Trakya University, Edirne, Turkey
}

\begin{abstract}
The aim of this study was to investigate the changes of some biochemical parameters during the amelioration after period o short term treatment of wheat with arsenic, cadmium and lead. A decrease was observed in the experimental groups, in which $15 \mu \mathrm{M}, 30 \mu \mathrm{M}$, and $60 \mu \mathrm{M}$ (arsenic, lead, and cadmium) metal ion mixture was applied, in terms of the germination rate depending on the increased concentration, and a decrease was observed in the root and stem dry weights of the plants in all groups. MDA levels were determined to increase at all doses. It was determined that heavy metals accumulated by increasing in the tissues due to the increased concentration of heavy metals in the heavy metal ion-applied groups. There were significant changes in the expression levels of antioxidant enzymes. As a result, it was determined in the study that there were significant changes in some biochemical and physiological parameter's which are the primary response to oxidative stress in plants exposed to heavy metals, depending on the stress. This reason it can be concluded that arsenic, lead and cadmium contents in media can be the responsible for growth inhibition.
\end{abstract}

Keywords: Wheat;germination; antioxidant enzymes; gen expression; MDA

\section{Introduction}

Plants are exposed to various stress factors during their growth and development. The most important environmental factors that cause stress on plants are mining, urban and industrial wastes, various substances such as pesticides, herbicides and artificial fertilizers used in agriculture and heavy metals given into the ecosystem through exhaust gases, which are released in traffic. While heavy metals such as cadmium, lead, and arsenic, leading to pollution in the ecosystem, cause heavy metal stress on cereal products with economic significance, they limit the growth of these products and decrease the product yield and quality [1].

Cadmium $(\mathrm{Cd})$ induces changes in the metabolism of fundamental substances such as nitrogen and carbohydrate found in the structure of plants. Moreover, it affects enzymes and the -SH groups in the structure of proteins, hinders photosynthesis by damaging the synthesis of enzymes which play a part in photosynthesis and causes a decrease in the water loss with transpiration by leading to stoma closure[2,3]. Cd is mixed into the soil via anthropogenic sources such as medicine and fertilizers used in agriculture, industrial and domestic wastes apart from its natural existence in soil $[4,5]$. In recent years, there has been a substantial increase in the $\mathrm{Cd}$ amount in soil because phosphorous fertilizers and sludge obtained in treatment systems have been used heavily [6]. Since $\mathrm{Cd}$ is dissolved in water, it is received by plant roots and carried to other tissues. $\mathrm{Cd}$ which accumulates in plants can reach humans through the food chain. It exhibits neurotoxic, mutagen and carcinogen effects in humans[7, 8]

Lead $(\mathrm{Pb})$ is given to the ecosystem with activities such as limestone and lead deposits in addition to pollution sources such as industrial factors and mining factors. Lead is naturally found in plants, but it is not an element which is absolutely necessary for plant growth. The toxic effect of lead changes depending on its density in the environment, the way it creates salt with other substances, the quality of the soil and the type of the plant. The toxic effect of lead in plants generally occurs with its

\footnotetext{
*email : filizsanal@trakya.edu.tr
} 
combination with the metal ions in the functional groups of macromolecules in the plant. Thus, it affects the growth events of the plant such as plant germination and root shooting by changing the activities of various enzymes regulating photosynthesis and the water content of the plant [9].

Arsenic is one of the heavy metals which are mostly found in the Earth's crust. Arsenic that is used as a raw material in agriculture, pharmacy and industry is a heavy metal with a quite toxic effect for living beings in the ecosystem. Especially inorganic arsenic (arsenate and arsenite) is highly toxic for plants because these substances dissolve phosphorylation in plants and inhibit the phosphate intake of the plant. When this substance reaches high concentrations in plants, it inhibits plant growth and even causes the death of the plant [10,11]. The most important sources through which arsenic enters the ecosystem are insecticides, herbicides, wood protectors, odorless dye production, mining, and coal deposits [12].

Heavy metals also cause an increase in reactive oxygen species such as superoxide radical, hydrogen peroxide, hydroxyl radical and singlet oxygen. The excessive production of reactive oxygen species leads to negative effects on the cellular structure and metabolism. Since reactive oxygen species cause oxidative damage in proteins, DNA and cell membranes, they can even lead to cell death. Like many types of living beings, plant cells can also struggle with ROS up to a certain level in enzymatic and non-enzymatic ways. The main elements of the enzymatic antioxidant defense in plants are superoxide dismutase (SOD), ascorbate peroxidase (APX), catalase (CAT) and glutathione synthase (GS)[13]. Vascular plants must respond quickly to changes in environmental conditions. The earliest response to the emerging stress is the inhibition of the root growth due to an increase in reactive oxygen species [14]. Due to environmental pollution, the concentrations of these metals in water and soil rose above the tolerable limits and threaten vitality. Therefore, in this study, it was investigated how the short-term arsenic, cadmium and lead application on "Saban", a variety of bread wheat registered in 2014 by the Thrace Agricultural Research Institute, affected some physiological and biochemical parameters and the gene expression levels of antioxidant enzymes during the germination period when some of the defense mechanisms had not been fully developed. The aim of this study was to analyses the effect of $\mathrm{As}, \mathrm{Cd}$ and $\mathrm{Pb}$ on some biochemical parameter through the assessment of oxidative stress indices at some physiological parameter and gene expression levels, heavy metals accumulation and using gen expression analysis that were studied. This study was performed in the germination period when some defense mechanisms were not fully developed because this is very important for product yield.

\section{Materials and methods}

\subsection{Plant Cultivation and Heavy Metal Application}

The seeds of the wheat species Triticum aestivum L. Emend Fiori et paol., developed by the Thrace Agricultural Research Institute as a result of adaptation studies, were used in the study. All the seeds used in the study were subjected to surface sterilization in $1.5 \%$ sodium hypochlorite solution for 10 min before they were left for germination in Petri dishes. The seeds subjected to surface sterilization were washed with distilled water a few times. Similarly, the Petri dishes, in which the seeds would germinate, were sterilized in the Pasteur oven at $120^{\circ} \mathrm{C}$ for $1 \mathrm{~h}$. Sterilized wheat seeds were placed between drying papers as 25 seeds in each Petri dish and left for germination in the plant growth chamber after the photoperiod application at $20^{\circ} \mathrm{C}$. Metal mixture solutions ( $\mathrm{As}, \mathrm{Pb}, \mathrm{Cd}$ ) freshly prepared for the experimental groups in $15 \mu \mathrm{M}, 30 \mu \mathrm{M}$ and $60 \mu \mathrm{M}$ concentrations were used. Distilled water was used as the irrigation water for the control group [15].

\subsection{The Effect of the Heavy Metal Mixture on Seed Germination}

Wheat seeds were watered with freshly prepared solutions containing metal mixture in $15 \mu \mathrm{M}, 30$ $\mu \mathrm{M}$ and $60 \mu \mathrm{M}$ concentrations ( $\mathrm{As}, \mathrm{Pb}, \mathrm{Cd}$ ) and left for incubation in the dark at $20^{\circ} \mathrm{C}$. For the control group, the seeds were watered with distilled water. On the $4^{\text {th }}$ day of germination, the ones with the radicle and plumule lengths more than $2-5 \mathrm{~mm}$ were accepted as germinated and the number of 
germinated seeds was determined. Germination percentages were calculated considering the number of the seeds germinated in the control Petri dishes.

\subsection{The Effect of the Heavy Metal Mixture on the Root, Stem Lengths, Fresh and Dry Weights}

For this study, wheat seeds were watered only with distilled water for 10 days before being exposed to heavy metal ion mixtures in different concentrations $(15 \mu \mathrm{M}, 30 \mu \mathrm{M}$, and $60 \mu \mathrm{M})$ and germinated. Heavy metal mixtures were applied at the end of the $10^{\text {th }}$ day. The root, stem lengths and fresh-dry weights of the groups were determined at the end of the $1^{\text {st }}$ and $5^{\text {th }}$ days. The longest root and the longest stem parts were measured from fibrous roots, and the root and stem lengths were recorded. The water was taken with the drying paper after the root and stem were cut, then fresh weights were found by weighing them on a precision scale. For determining the dry weight, the roots and stems were left for drying in the drying oven at $80^{\circ} \mathrm{C}$ for $24 \mathrm{~h}$. Dry weights were determined at the end of the drying process.

\subsection{Measurement of Lipid Peroxidation}

The thiobarbituric acid (TBA) method was used to measure lipid peroxidation in the root and stem. The determination of MDA, which is the final product of lipid peroxidation, was performed according to Sun et al. (2008)[16].

Fresh $0.5 \mathrm{~g}$ root and stem samples were separated from the germinated seeds and frozen at $-80^{\circ} \mathrm{C}$. Frozen samples were homogenized in a glass homogenizer in $0.25 \%$ TBA prepared in $10 \%$ trichloroacetic acid (TCA). The extract was boiled at $95^{\circ} \mathrm{C}$ for $30 \mathrm{~min}$. It was cooled down quickly and centrifuged at $10.000 \mathrm{x} \mathrm{g}$ for $10 \mathrm{~min}$. The absorbance of the supernatant was measured at $532 \mathrm{~nm}$ and $600 \mathrm{~nm}$. The level of lipid peroxidation was calculated using the $1.55 \mathrm{mM} \mathrm{cm}^{-1}$ extinction coefficient.

\subsection{The Effect of the Heavy Metal Mixture on the Root and Stem Protein Amounts}

Protein extraction was performed according to Sanal et al. (2014) in root and stem samples frozen at $-80^{\circ} \mathrm{C}$ [15]. Protein determination in the plant was performed spectrophotometrically according to the Lowry method. The protein amounts in the root and stem were presented in $\mathrm{mg} / \mathrm{ml}$.

\subsection{Determination of the Gene Expression Levels of Antioxidant Enzymes}

$0.2 \mathrm{~g}$ fresh stem was homogenized with the help of liquid nitrogen particles and beads in the appropriate buffer for the expression analyses of enzymes from the samples to which application was performed. For the total RNA isolation from tissues, the Total RNA PureLink® RNA Mini Kit (Life Sciences) was used. Isolation was performed according to the RNA kit protocol. The RNA amounts isolated from the plant tissues were determined by a Qubit ${ }^{\circledR}$ Fluorometer (Invitrogen), and PCR conditions were programmed to be Step $1: 25^{\circ} \mathrm{C}, 10 \mathrm{~min}$; Step 2: $37^{\circ} \mathrm{C}, 120 \mathrm{~min}$; Step 3: $85^{\circ} \mathrm{C}, 5 \mathrm{~min}$ using the High Capacity cDNA Reverse Transcription Kit (Applied Biosystems), and the cDNA synthesis was carried out. The cDNA obtained was kept at $-20 \mathrm{C}$ to be used in future analyses. Primers suitable for enzymes were selected, and changes in gene expressions were monitored. The following primers were used, and the gene expressions were determined in compliance with the SYBR Green qPCR mastermix protocol in RT-PCR:

SOD; F (5'-GTTCGGTGACAACACCAATG-3') and R(5'-GGAGTCGGTGATGTTGACCT-3'),

CAT:F(5'-TACGAGCAGGCCAAGAAGTT-3') and R(5'-ACCTTGTACGGGCAGTTCAC-3'),

GS: F (5'-TGGGACCAGCAAGTAAAACC-3') and R(5'-TCGCGAATG TAGAACTCGTG-3').

As the correction factor, the housekeeping gene GAPDH: and the primers F (5'- TTGGTATCGTG GAAGGACTCA-3') and (5'- TGTCATCATATTTGGCAGGTTT-3') were used. 
The $\boldsymbol{\Delta} \boldsymbol{\Delta} \mathrm{Ct}$ method was used for determining the gene expression differences between the groups in Real Time PCR studies. As the calibration curve and the correction factor, GAPDH and 18S gene expressions were used.

\subsection{Heavy Metal Determination in Plant Samples}

For the heavy metal determination, a $0.5 \mathrm{~g}$ plant sample was taken at the end of the germination period, washed with deionized water and excess water were removed with blotter; then the fresh weights were recorded. Plant tissues were taken from each experimental group, added with $65 \%$ nitric acid solution and completed to $10 \mathrm{~mL}$ in total. They were fired and homogenized according to the usage protocol in the CEM Mars 6 microwave firing system (Power: 1030-1800, temperature: 180, Ramp Time 20.00-25.00, Hold Time: 10: 00). $1 \mathrm{~mL}$ was taken from the product obtained and dilueted to $2 \%$ nitric acid, and the metal amounts accumulated in tissues were determined in Agilent $7700 \mathrm{x}$ ICP-MS.

\section{Results and discussions}

\subsection{The Effect of the Heavy Metal Mixture on Seed Germination}

A decrease was observed in the germination rate due to the concentration increase in the experimental groups to which the heavy metal mixture was applied (Table 1).

Table 1 The effect of the heavy metal

mixtures on seed germination

\begin{tabular}{|c|c|}
\hline $\begin{array}{c}\text { The concentration of } \\
\text { metal ions }(\mu \mathrm{M})\end{array}$ & $\begin{array}{c}\text { Germination } \\
\text { percentage } \\
(\%)\end{array}$ \\
\hline Control & 70 \\
\hline $\mathbf{1 5}$ & 57 \\
\hline $\mathbf{3 0}$ & 49 \\
\hline $\mathbf{6 0}$ & 34 \\
\hline
\end{tabular}

\subsection{The Effect of the Heavy Metal Mixture on the Root and Stem Lengths}

Both shoot and root lengths reduced significantly under increasing concentrations of arsenic. From $11.65 \mathrm{~cm}$ in the control, root length dropped to $10.03 \mathrm{~cm}$ at $60 \mu \mathrm{M}$ As. Hovewer length of stem also showed a increase at $15 \mu \mathrm{M}$ As. But length of stem also showed a linear decrease on increasing arsenic doses in 1 st day. At the end of the $5^{\text {th }}$ day Similarly, length of root and stem also showed a linear decrease on increasing arsenic doses (Figure 1and Figure 2).

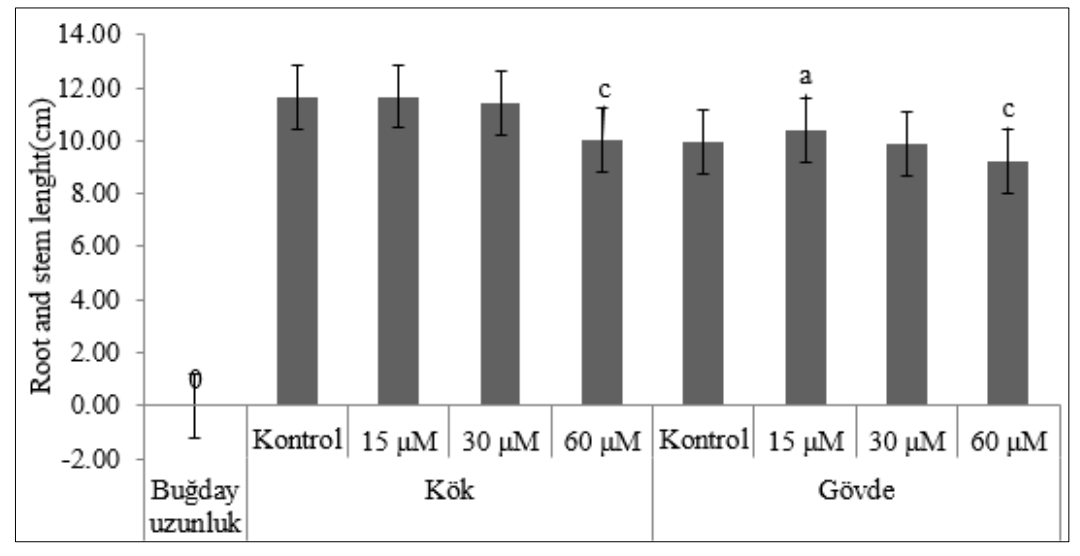

Figure 1. The change in the wheat root and stem lengths compared to the control group at the end of the $1^{\text {st }}$ day a: $15 \mu \mathrm{M}$ comparison with control group $\mathrm{p}<0.05 \mathrm{c}: 60 \mu \mathrm{M}$ comparison with control group $\mathrm{p}<0.05$ 


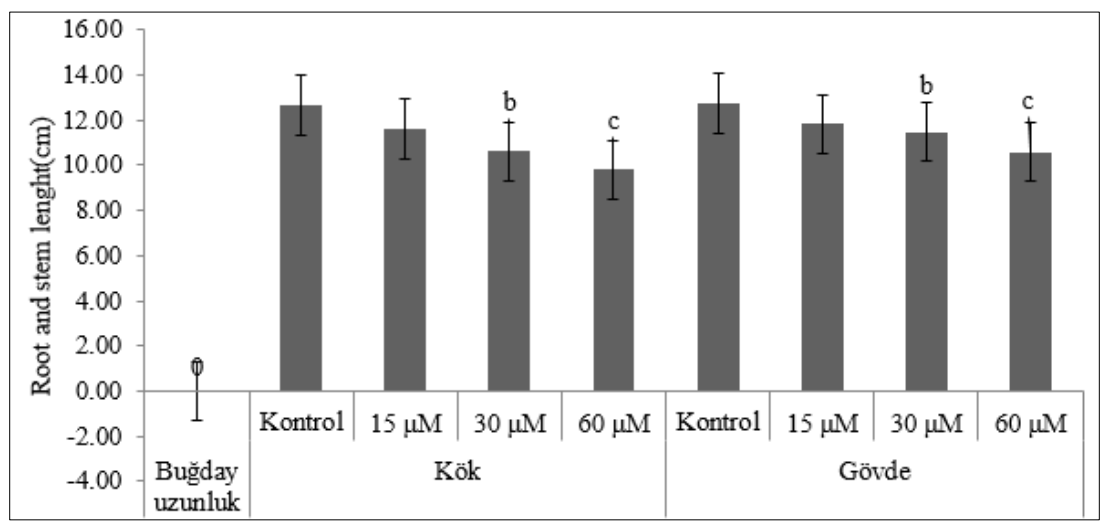

Figure 2 The change in the wheat root and stem lengths compared to the control group at the end of the $5^{\text {th }}$ day b: $30 \mu \mathrm{M}$ comparison with Control group $\mathrm{p}<0.05 \mathrm{c}$ : $60 \mu \mathrm{M}$ comparison with control group $\mathrm{p}<0.05$

\subsection{The Effect of the Heavy Metal Mixture on the Fresh and Dry Weights of the Root and Stem}

When the fresh and dry weights of the wheat roots were compared to the control group at the end of the $1^{\text {st }}$ day, an increase in fresh weights was observed in $15 \mu \mathrm{M}$ dose application, and a decrease in fresh weights was observed in $30 \mu \mathrm{M}$ and $60 \mu \mathrm{M}$ dose applications. It was observed that dry weights decreased significantly in all the doses compared to the control group. When the fresh stem weights were compared to the control group, a decrease was observed in $15 \mu \mathrm{M}$ dose application, an increase was observed in $30 \mu \mathrm{M}$ dose, and again a decrease was observed in $60 \mu \mathrm{M}$ dose application. Dry stem weights decreased in all the groups compared to the control group. The change in the fresh and dry weights on the $1^{\text {st }}$ day shows similarity in the root and stem. The fresh and dry weights of the wheat root and stem decreased in all the doses when compared to the control group at the end of the $5^{\text {th }}$ day. (Table 2)

Table 2 The Effect of the Heavy Metal Mixture on the Fresh and Dry Weights of the Root and Stem

\begin{tabular}{|c|c|c|c|c|}
\hline \multirow{2}{*}{$\begin{array}{l}\text { (As, } \mathrm{Pb}, \mathrm{Cd}) \text { The } \\
\text { concentration of the } \\
\text { mixture }(\mu \mathrm{M})\end{array}$} & \multicolumn{2}{|c|}{$\begin{array}{c}\text { Wheat root } \\
\text { 1st day }\end{array}$} & \multicolumn{2}{|c|}{$\begin{array}{l}\text { Wheat root } \\
5 \text { h day }\end{array}$} \\
\hline & Root fresh weight (g) & $\begin{array}{l}\text { Root dry } \\
\text { weight (g) }\end{array}$ & Root fresh weight (g) & $\begin{array}{l}\text { Root dry } \\
\text { weight (g) }\end{array}$ \\
\hline Control & 0.97 & 0.09 & 1.31 & 0.10 \\
\hline $15 \mu \mathrm{M}$ & 1 & 0.06 & 0.93 & 0.08 \\
\hline $30 \mu \mathrm{M}$ & 0.95 & 0.07 & 0.94 & 0.08 \\
\hline $\mathbf{6 0} \mu \mathrm{M}$ & 0.75 & 0.05 & 0.92 & 0.09 \\
\hline \multirow{2}{*}{$\begin{array}{l}\text { (As, } \mathrm{Pb}, \mathrm{Cd}) \text { The } \\
\text { concentration of the } \\
\text { mixture }(\mu \mathrm{M})\end{array}$} & \multicolumn{2}{|c|}{$\begin{array}{c}\text { Wheat stem } \\
\text { 1st day }\end{array}$} & \multicolumn{2}{|c|}{$\begin{array}{c}\text { Wheat stem } \\
\text { 5th day }\end{array}$} \\
\hline & $\begin{array}{l}\text { Stem fresh weight } \\
(\mathrm{g})\end{array}$ & $\begin{array}{l}\text { Stem dry weight } \\
(\mathrm{g})\end{array}$ & $\begin{array}{l}\text { Stem fresh weight } \\
(\mathrm{g})\end{array}$ & $\begin{array}{l}\text { Stem Dry weight } \\
(\mathrm{g})\end{array}$ \\
\hline Control & 1.66 & 0.18 & 2.39 & 0.24 \\
\hline $15 \mu \mathrm{M}$ & 1.46 & 0.14 & 2.33 & 0.22 \\
\hline $30 \mu \mathrm{M}$ & 1.67 & 0.16 & 2.20 & 0.22 \\
\hline $60 \mu \mathrm{M}$ & 1.55 & 0.16 & 2.28 & 0.23 \\
\hline
\end{tabular}

\subsection{Measurement of Lipid Peroxidation}

When the groups in which metal application was performed in the root and stem samples were compared to the control group at the end of the $1^{\text {st }}$ and $5^{\text {th }}$ days, an MDA increase in the root at the dose of $15 \mu \mathrm{M}$ was not found significant ( $\mathrm{p}>0.05$ ), and an increase in the MDA level was observed in all the other groups $(\mathrm{p}<0.05)$ (Figure $3-4)$. 


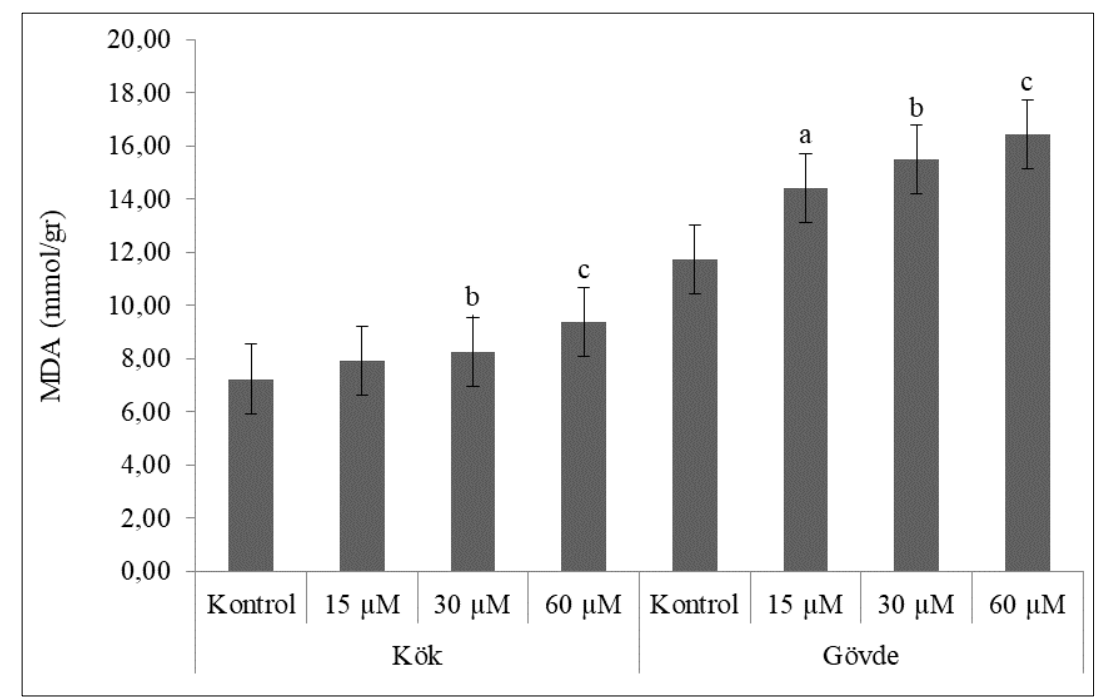

Figure 3 At the end of the 1st day MDA content in wheat root and stem a: $15 \mu \mathrm{M}$ comparison with control group $\mathrm{p}<0.05$ b: $30 \mu \mathrm{M}$ comparison with Control group $\mathrm{p}<0.05$ c: $60 \mu \mathrm{M}$ comparison with control group $\mathrm{p}<0.05$

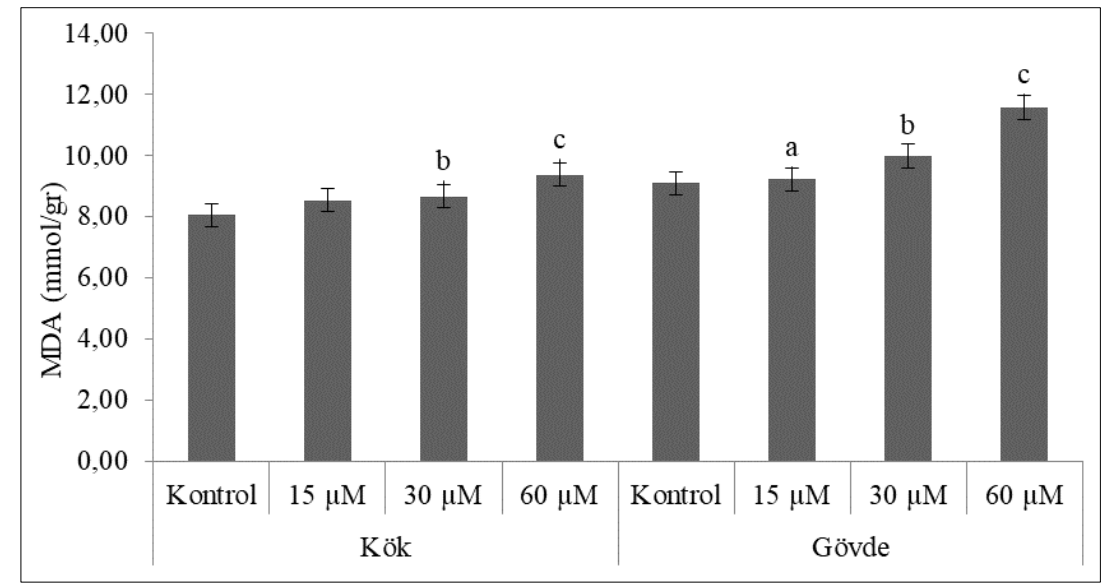

Figure 4 At the end of the 5th day, MDA content in wheat root and Stem a: $15 \mu \mathrm{M}$ comparison with control group $\mathrm{p}<0.05 \mathbf{b}: 30 \mu \mathrm{M}$ comparison with control group $\mathrm{p}<0.05$ c: $60 \mu \mathrm{M}$ comparison with control group $\mathrm{p}<0.05$

\subsection{Determination of the Total Protein Content in the Root and Stem}

When the protein contents of roots were compared to the control group at the end of the $1^{\text {st }}$ day, the protein content increased in all the groups in which metal application was performed. However, this increase was not found statistically significant $(p>0.05)$. The protein content of only the groups to which the dose of $60 \mu \mathrm{M}$ was applied increased significantly in stem samples $(\mathrm{p}<0.05)$.

While there was no significant change in groups to which the doses of $15 \mu \mathrm{M}$ and $60 \mu \mathrm{M}$ were applied in terms of the protein contents of roots at the end of the $5^{\text {th }}$ day $(p>0.05)$, a decrease was observed in $30 \mu \mathrm{M}$ dose application $(\mathrm{p}<0.05)$. At the end of the $5^{\text {th }}$ day, the protein content of the groups to which the doses of $15 \mu \mathrm{M}$ and $30 \mu \mathrm{M}$ were applied decreased in the stem samples compared to the control group $(\mathrm{p}<0.05)$. In $60 \mu \mathrm{M}$ dose application, the protein amounts increased again and approached the control group. However, this increase was not found statistically significant $(\mathrm{p}>0.05)$. (Figure 5-6) 


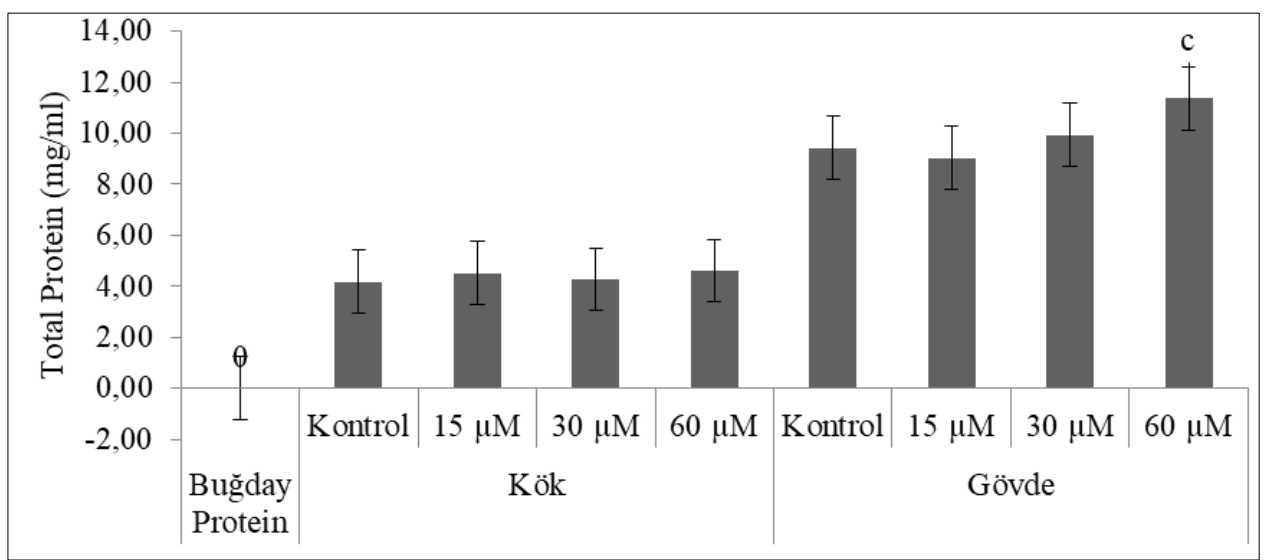

Figure 5 Total protein contents in wheat root and stem at the end of 1 st day c: $60 \mu \mathrm{M}$ comparison with control group , $\mathrm{p}<0.05$

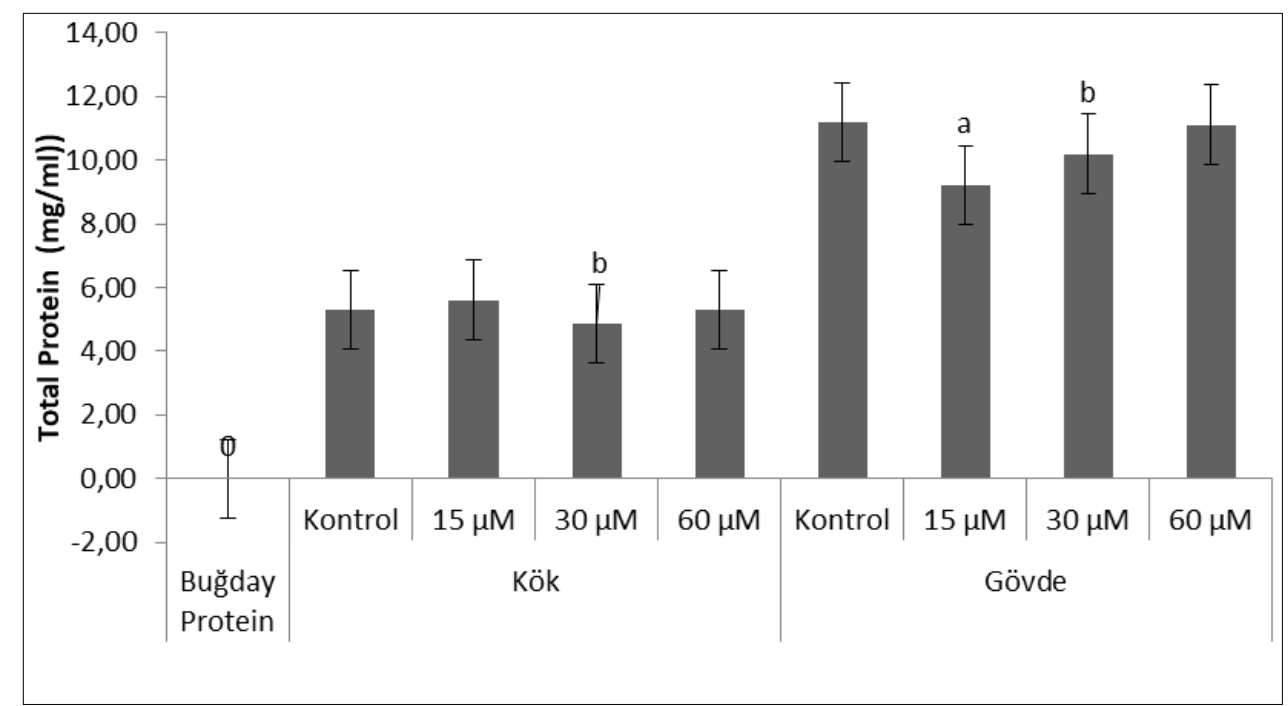

Figure 6 Total protein contents in wheat root and stem at the end of 5th day. a: $15 \mu \mathrm{M}$ comparison with control group, $\mathrm{p}<0.05$ b: $30 \mu \mathrm{M}$ comparison with control group, $\mathrm{p}<0.05$

\subsection{The Effect of the Heavy Metal Mixture Application on the Gene Expression Levels of Antioxidant Enzymes}

Changes in the antioxidant enzyme levels, which are the primary responses of the plant to metal stress related to $\mathrm{As}, \mathrm{Cd}$, and $\mathrm{Pb}$ on wheat, were examined on the basis of the expression levels of these enzymes, $\beta$ actin gene levels selected as the reference gene.

At the end of the day, it was observed that the gene expression of the GS enzyme increased in all the doses compared to the control group, the expression of the SOD enzyme decreased in $15 \mu \mathrm{M}$ dose application, and there was an increase in the other two doses. While the gene expression of the CAT and GPX enzymes decreased at $15 \mu \mathrm{M}$, it increased together with the dose increase. At the end of the $5^{\text {th }}$ day, a decrease was observed at $15 \mu \mathrm{M}$ in the gene expression of the CAT enzyme, and the expression increased together with the dose increase. The gene expression of the GPX enzyme increased in all the doses compared to the control group (Figure 7,8). 


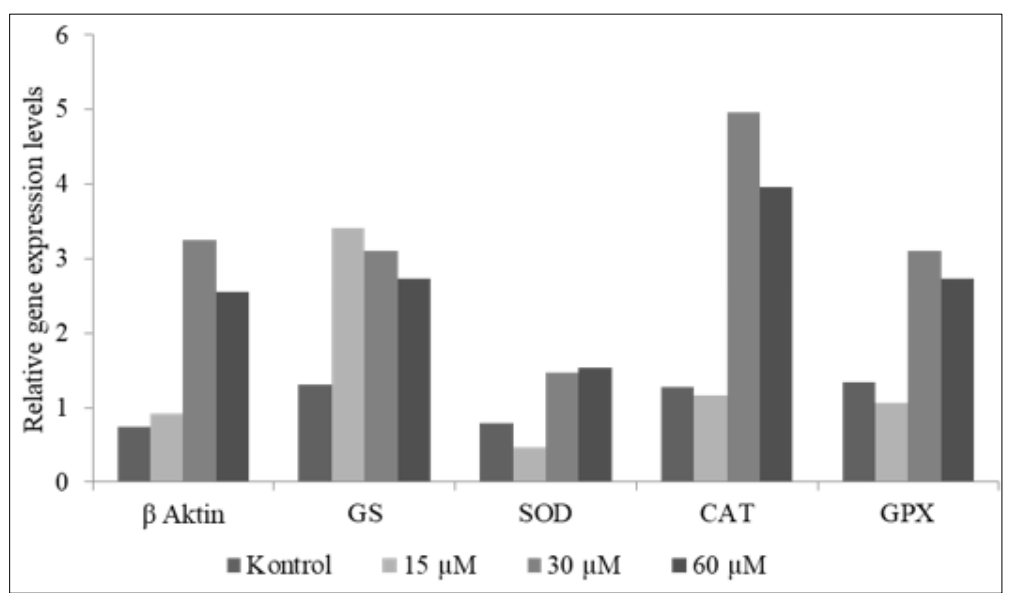

Figure 7 At the end of the 1st day the levels of gene expression of antioxidant enzymes

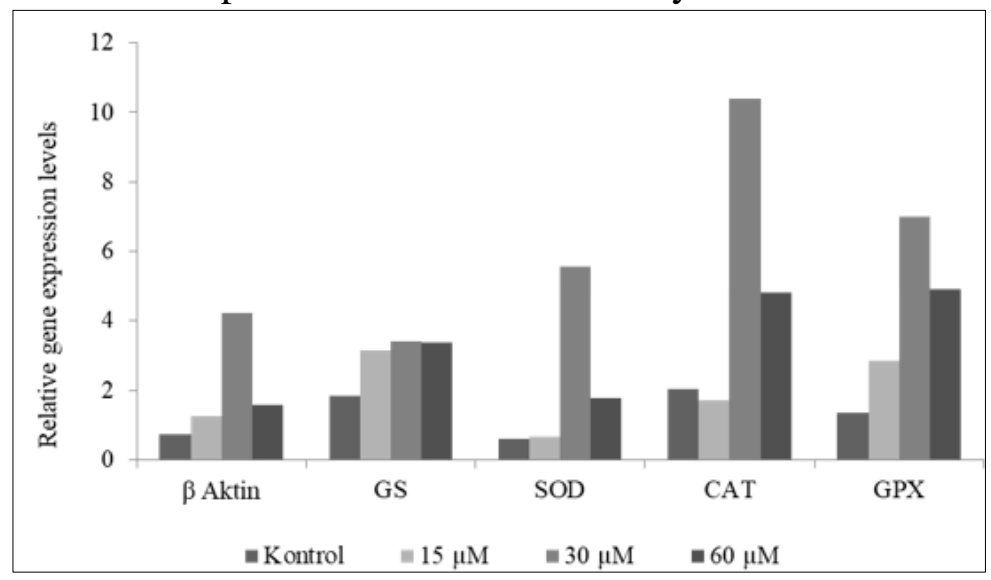

Figure 8 At the end of the 5th day the levels of gene expression of antioxidant enzymes

\subsection{Heavy Metal Accumulation}

An increase was observed in the heavy metal accumulation in parallel with the dose increase in the plant when compared to the control group at the end of the $1^{\text {st }}$ and $5^{\text {th }}$ days (Table 3 ).

Table 3 Heavy metal accumulation (ppb) in wheat at the end of the $1^{\text {st }}$ and $5^{\text {th }}$ days (Values are the mean of the triplicated experiments)

\begin{tabular}{|c|c|c|c|c|c|c|c|c|}
\hline & $\begin{array}{c}\text { Control } \\
\mathbf{1} \text { st day }\end{array}$ & $\begin{array}{c}\mathbf{1 5} \boldsymbol{\mu M} \\
\mathbf{1} \text { st day }\end{array}$ & $\begin{array}{c}\mathbf{3 0 \mu M} \\
\mathbf{1} \mathbf{s t} \text { day }\end{array}$ & $\begin{array}{c}\mathbf{6 0 \mu M} \\
\mathbf{1} \text { st day }\end{array}$ & $\begin{array}{c}\text { Control 5 } \\
\text { th day }\end{array}$ & $\begin{array}{c}\mathbf{1 5} \boldsymbol{\mu M} \\
\mathbf{5} \text { th day }\end{array}$ & $\begin{array}{c}\mathbf{3 0} \boldsymbol{\mu M} \\
\mathbf{5} \text { th day }\end{array}$ & $\begin{array}{c}\mathbf{6 0} \boldsymbol{\mu M} \\
\mathbf{5} \text { th day }\end{array}$ \\
\hline $\mathbf{A s}$ & 0.093 & 0.333 & 0.369 & 1.596 & 0.115 & 0.462 & 0.987 & 1.84 \\
\hline $\mathbf{C d}$ & 0.038 & 0.325 & 0.368 & 1.074 & 0.066 & 1.11 & 1.846 & 3.172 \\
\hline $\mathbf{P b}$ & 0.484 & 0.715 & 0.763 & 2.289 & 0.79 & 1.384 & 2.74 & 3.133 \\
\hline
\end{tabular}

Heavy metals, which are among the significant causes of environmental pollution, affect plants macroscopically, microscopically and physiologically. Heavy metals can be present in our food from various sources, and this affects human health negatively. The fact that heavy metals can be transmitted to the foodstuff of humans is considered as a health problem.

Fertilizers and treatment sludge are used to increase the yield in agriculture. Agricultural lands around the world are exposed to heavy metal pollution at different levels due to the excessive use of 
phosphatic fertilizers and the heavy metal content of treatment sludge. Since Cd is more mobile compared to other metals, its transition from soil to plants occurs more often, and it is included in the food chain in this way. It also constitutes a significant threat to human and animal health and the environment. $42 \%$ of $\mathrm{Cd}$ taken into the human body comes from cereals $[17,18]$.

In many countries, people use the underground water polluted with arsenic. Therefore, drinking and underground waters containing arsenic continue to threaten seriously both the environment and human health as a significant problem all over the world. The most important sources through which arsenic enters the ecosystem are insecticides, herbicides, wood protectors, odorless dye production, mining, and coal deposits[12]. As a result of the environmental pollution, arsenic reaches humans through drinking water and nutrition by affecting aquatic ecosystems similarly to terrestrial ecosystems. In addition to the pollution sources such as industrial and mining factors, lead, which is given to the ecosystem with activities such as limestone and lead deposits, is naturally found in plants, but it is not an element that is absolutely necessary for plant growth.

In the present study, heavy metal mixtures applied to wheat seeds caused a decrease in the germination rate in the seeds together with the concentration increase. Similarly, Shri et al. (2009) stated in their study conducted on wheat seeds that arsenic decreased the germination percentage in the plant significantly along with the dose increase [19]. Again, the effect of lead $\left(\mathrm{PbCl}_{2}\right)$ on the germination of lentil (Lens culinaris) seeds was investigated, and it was determined that low lead concentrations do not have a negative effect on germination, but high concentrations inhibit germination [20]. The results are similar to the present study.

When the wheat root-stem lengths were compared to the control group, a significant decrease was detected only in $60 \mu \mathrm{M}$ metal application on the $1^{\text {st }}$ day $(\mathrm{p}<0.05)$, while a decrease was observed at 30 $\mu \mathrm{M}$ and $60 \mu \mathrm{M}$ on the $5^{\text {th }}$ day $(\mathrm{p}<0.05)$. It was reported in the study conducted by Gonzales et al. (2017) that heavy metal mixtures decreased the root-stem lengths and biomass in wheat and barley significantly [21]. It was reported in many other studies that a short-term heavy metal application suppressed growth, photosynthesis, and respiration and increased the secondary metabolite production $[11,22]$. The toxic effect of lead in plants is the restriction of root growth and development, dwarfing and chlorosis[23]. According to the observations in the present study, local browning and chlorosis were observed on plant leaves and roots together with the concentration increase. Moreover, the roots were observed to be shorter compared to normal plant roots together with the dose increase, and a decrease was observed in the lateral roots. As the metal intake continued, a significant regression was observed in the root and stem development at the end of the $5^{\text {th }}$ day. Decreases were observed in the fresh and dry root and stem weights as a result of the slowdown in the root and stem elongation. Likewise, it was reported that zinc and arsenate mixtures, which are among the significant toxicants in mining excavation sites, inhibited root elongation in barley [24]. Fargašová (2001) stated that a decrease occurred in the fresh and dry root weights and lead accumulated in the root in the garlic exposed to $\mathrm{Pb}$ stress.[25]. In many studies, high concentrations of heavy metals are similarly said to cause decreases in seed germination, root and stem lengths and root-stem weights in plants [22, 26-29].

Upon assessing the protein amount in wheat, an increase was determined at $60 \mu \mathrm{M}$ only on the $1^{\text {st }}$ day $(\mathrm{p}<0.05)$. While there was no significant change in the protein amount in $15 \mu \mathrm{M}$ and $60 \mu \mathrm{M}$ metal applications in the wheat root on the $5^{\text {th }}$ day, a decrease was observed at $30 \mu \mathrm{M}(\mathrm{p}<0.05)$. Whereas a decrease was detected in the stem at $15 \mu \mathrm{M}$ and $30 \mu \mathrm{M}$ compared to the control group $(\mathrm{p}<0.05)$, no significant change was observed in $60 \mu \mathrm{M}$ application. It was observed in the study conducted by Sanal et al. (2014) with barley seeds that the total protein amount decreased in roots in $0.5,1,2,4,8$, $16 \mathrm{mM}$ sodium arsenate and sodium arsenite applications[15].

There is an increase in MDA levels in all groups in the study. The measurement of the MDA amount is a stress indicator used for the determination of lipid peroxidation levels [30]. The MDA level may increase under $\mathrm{Zn}$ stress according to Chaoui et al. (1997) and under $\mathrm{Cd}$ and $\mathrm{Cu}$ stress according to Dey et al. (2007) [31, 32]. In a similar study, the MDA amount was found to have increased in two different barley species as the selenium dose increased under the selenium toxicity 
[33]. There are many studies stating that the heavy metal application triggered oxidative stress and consequently increased the MDA amounts [22, 28, 34].

It was found out on the $1^{\text {st }}$ and $5^{\text {th }}$ days that heavy metals increased and accumulated in tissues together with the concentration increase in the metal ion applied groups compared to the control group. In a study investigating chrome accumulation in Indian lotus Nelumbo nucifera, similar results were observed in the tissues of the plant grown at different chrome concentrations $(50-200 \mu \mathrm{m})$. The highest accumulation was reported in the roots [35]. Topcuoğlu et al. investigated the effects of different urban treatment sludges applied to the soil for two years on the plant nutritional elements in the tomato plant and the heavy metal level in their contents and detected a significant increase in the heavy metal (N, $\mathrm{P}$, $\mathrm{K}, \mathrm{Ca}, \mathrm{Mg}, \mathrm{Zn}, \mathrm{Mn}, \mathrm{Cu}, \mathrm{Pb}, \mathrm{Ni}$ and $\mathrm{Cd}$ ) contents of the tomato plant in parallel with the treatment sludge applied in increasing amounts [36] . Khan et al. (2009) reported in their study conducted on the mustard plant that 5 and $25 \mu \mathrm{M}$ arsenic application increased the arsenic content in the root and stem together with the dose after $96 \mathrm{~h}$ [37].

The gene expression levels of the assessed SOD, GS, GPX and CAT antioxidant enzymes decreased at $15 \mu \mathrm{M}$ but increased in a way to show that the defense system was activated depending on the time and dose. Similarly, an increase was observed in the SOD activity in the studies conducted under stress conditions in plants such as Morus alba L. (mulberry), Cicer arietinum L. (chickpea) and L. esculentum (tomato) [38, 39].

It was shown in the studies investigating the expression levels of the genes coding the SOD enzyme that changes occurred in the gene expression under various stress conditions and depending on the plant species, and these changes played a role in the stress defense [34, 40-42] . Similarly, it was shown that the expression levels of the genes, which code the catalase enzyme in many plants such as L. esculentum (tomato), Hordeum vulgare (barley), Corylus maxima Mill. (nut) increased depending on the stress $[41,43,44]$. The short-term cadmium application was reported to result in root inhibition and a decrease in the GPX expression [29]. Furthermore, it was observed that high cadmium concentrations $(60 \mu \mathrm{M})$ suppressed the expression of the CAT enzyme significantly [13].

In communities that are industrializing quickly nowadays, industrial and urban wastes, the unconscious use of pesticides and fertilizers raise the levels of heavy metals which may have toxic effects above the limit values in the soil and water. In many studies in the literature, changes were reported in the activities of antioxidant enzymes, which are the primary response of oxidant stress in many plants exposed to heavy metals [29, 34].

Different response of antioxidant enzyme activities to heavy metal toxicity has been reported. Navabpour et al. (2020) reported increased SOD, and CAT activities under lead toxicity in wheat.[45] In addition to this, Li et al. (2013) in Pistia stratiotes L., [29, 34] and Zolinova et al. (2013) in barley have shown increased SOD and CAT activity under cadmium toxicity [29]. Similarly, Dube et al. (2009) reported that excess Cadmium increased GPX activity in barley [46]. Murzaeva 2004 has reported that the increase in APX, SOD, POD activities could be represent an appropriate protection against overproduction of peroxides when As accumulated in wheat [47]. Saleh et al.(2020) showed that lead significantly decreased the vegetative growth parameters, altered the activities of antioxidants enzymes in wheat seedlings and differently affected their expression levels in seedlings leaves and roots in wheat [48]. Dey et al 2007 has been detected that under Pb stress, the induction in SOD activity and declined in CAT activity were sharper in root tissues than in their shoot in wheat. The POX activity increased both in roots and shoots under Pb stress. It has been observed malondialdehyde concentration increased in both roots and shoots of $\mathrm{Cd}$ - and $\mathrm{Pb}$-treated seedlings in their study [32].

\section{Conclusions}

Since changes in the gene expression levels of some enzymes coming to the forefront in the antioxidant defense in the present study comply with the data on the activity changes in the literature, the determination of the expression levels of these enzymes will provide researchers with significant information about the course of the defense mechanisms when plants are exposed to heavy metals 
during the germination period. Wheat that was exposed to heavy metals in accordance with the literature was affected negatively in terms of physiological parameters in a period during which its defense systems had not developed fully yet, and heavy metal accumulation was observed even in the short-term application. This also indicates that the negative effects of environmental pollution are observed on plants very quickly.

Acknowledgement: We would like to express our appreciation to the Trakya University Scientific Research Project Commission, which supported this study (TUBAP 2015-38). This study is part of postgraduate thesis of Hulya Y1ld.

\section{References}

1. SHANKER, A.K., CERVANTES, C., LOZA-TAVERA, H., AVUDAINAYAGAM, S. Chromium toxicity in plants, Environ Int, 31 (2005) 739-753.

2. SHEORAN, I., AGGARWAL, N., SINGH, R. Effects of cadmium and nickel on in vivo carbon dioxide exchange rate of pigeon pea (Cajanus cajan L.), Plant and soil, 129 (1990) 243-249.

3. ZENGİN, F.K., MUNZUROĞLU, Ö. Fasulye fidelerinin (Phaseolus vulgaris L.) kök, gövde ve yaprak büyümesi üzerine kadmiyum $(\mathrm{Cd}++)$ ve Civa $(\mathrm{Hg}++)$ 'nın etkileri, Fen Bilimleri Dergisi, 24 (2003) 64-75.

4. MANTA, D.S., ANGELONE, M., BELLANCA, A., NERI, R., SPROVIERI, M. Heavy metals in urban soils: a case study from the city of Palermo (Sicily), Italy, Science of the total environment, 300 (2002) 229-243.

5. KOMARNICKI, G.J. Lead and cadmium in indoor air and the urban environment, Environmental Pollution, 136 (2005) 47-61.

6. TÜRKMEN, Ö., ŞENSOY, S., ÇIRKA, M. The effect of sewage sludge on the emergence and seedling growth in cucumber, Yüzüncü Y1l Üniversitesi Tarım Bilimleri Dergisi, 11 (2001) 1-4.

7. DALCORSO, G., FARINATI, S., FURINI, A. Regulatory networks of cadmium stress in plants, Plant signaling \& Behavior, 5 (2010) 663-667.

8. GILL, S.S., KHAN, N.A., ANJUM, N.A., TUTEJA, N. Amelioration of cadmium stress in crop plants by nutrients management: morphological, physiological and biochemical aspects, Plant Stress, 5 (2011) 1-23.

9. LAMHAMDI, M., BAKRIM, A., AARAB, A., LAFONT, R., SAYAH, F. Lead phytotoxicity on wheat (Triticum aestivum L.) seed germination and seedlings growth, Comptes rendus biologies, 334 (2011) 118-126.

10. GENG, C.N., ZHU, Y.-G., TONG, Y.-P., SMITH, S.E., SMITH, F. Arsenate (As) uptake by and distribution in two cultivars of winter wheat (Triticum aestivum L.), Chemosphere, 62 (2006) 608-615.

11. ISLAM, E., KHAN, M.T., IREM, S. Biochemical mechanisms of signaling: perspectives in plants under arsenic stress, Ecotoxicology and environmental safety, 114 (2015) 126-133.

12. CASTILLO-MICHEL, H., PARSONS, J., PERALTA-VIDEA, J., MARTINEZ-MARTINEZ, A., DOKKEN, K., GARDEA-TORRESDEY, J. Use of X-ray absorption spectroscopy and biochemical techniques to characterize arsenic uptake and reduction in pea (Pisum sativum) plants, Plant Physiology and Biochemistry, 45 (2007) 457-463.

13. BOČOVÁ, B., HUTTOVÁ, J., LIPTÁKOVÁ, L., MISTRÍK, I., OLLÉ, M., TAMÁS, L. Impact of short-term cadmium treatment on catalase and ascorbate peroxidase activities in barley root tips, Biologia Plantarum, 56 (2012) 724-728.

14. POTTERS, G., PASTERNAK, T.P., GUISEZ, Y., JANSEN, M.A. Different stresses, similar morphogenic responses: integrating a plethora of pathways, Plant, Cell \& Environment, 32 (2009) 158169.

15. SANAL, F., SEREN, G., GUNER, U. Effects of arsenate and arsenite on germination and some physiological attributes of barley Hordeum vulgare L, Bulletin of environmental contamination and toxicology, 92 (2014) 483-489. 
16. SUN, Y., Lİ, Z., GUO, B., CHU, G., WEİ, C., LIANG, Y. Arsenic mitigates cadmium toxicity in rice seedlings, Environmental and Experimental Botany, 64 (2008) 264-270.

17. YSART, G., Miller, P., CROASDAlE, M., CREWS, H., ROBB, P., BAXTER, M., DE L'ARGY, C., HARRISON, N. 1997 UK Total Diet Study dietary exposures to aluminium, arsenic, cadmium, chromium, copper, lead, mercury, nickel, selenium, tin and zinc, Food Additives \& Contaminants, 17 (2000) 775-786.

18. SHE, W., ZHU, S., JIE, Y., XING, H., CUI, G. Expression profiling of cadmium response genes in ramie (Boehmeria nivea L.) root, Bulletin of Environmental Contamination and Toxicology, 94 (2015) 453-459.

19. SHRI, M., KUMAR, S., CHAKRABARTY, D., TRIVEDI, P.K., MALLICK, S., MISRA, P., SHUKLA, D., MISHRA, S., SRIVASTAVA, S., TRIPATHI, R.D. Effect of arsenic on growth, oxidative stress, and antioxidant system in rice seedlings, Ecotoxicology and environmental safety, 72 (2009) 1102-1110.

20. AZMAT, R., HAIDER, S., ASKARI, S. Phyotoxicity of Pb: I effect of Pb on germination, growth, morphology and histomorphology of Phaseolus mungo and Lens culinaris, Pak. J. Biol. Sci, 9 (2006) 979-984.

21. GONZÁLEZ, A., GIL-DÍAZ, M.M., PINILLA, P., LOBO, M.C. Impact of Cr and Zn on Growth, Biochemical and Physiological Parameters, and Metal Accumulation by Wheat and Barley Plants, Water, Air, \& Soil Pollution, 228 (2017) 419.

22. NATH, S., PANDA, P., MISHRA, S., DEY, M., CHOUDHURY, S., SAHOO, L., PANDA, S.K. Arsenic stress in rice: redox consequences and regulation by iron, Plant Physiology and Biochemistry, 80 (2014) 203-210.

23. POURRUT, B., SHAHID, M., DOUAY, F., DUMAT, C., PINELLI, E. Molecular mechanisms involved in lead uptake, toxicity and detoxification in higher plants, in: Heavy Metal Stress in Plants, Springer, 2013, pp. 121-147.

24. GUZMÁN RANGEL, G., VERSIEREN, L., QIU, H., SMOLDERS, E. Additive toxicity of zinc and arsenate on barley (Hordeum vulgare) root elongation, Environmental Toxicology and Chemistry, 36 (2017) 1556-1562.

25. FARGAŠOVÁ, A. Phytotoxic effects of $\mathrm{Cd}, \mathrm{Zn}, \mathrm{Pb}, \mathrm{Cu}$ and $\mathrm{Fe}$ on Sinapis alba L. seedlings and their accumulation in roots and shoots, Biologia Plantarum, 44 (2001) 471-473.

26. OGUNKUNLE, C.O., ODULAJA, D.A., AKANDE, F.O., VARUN, M., VISHWAKARMA, V., FATOBA, P.O. Cadmium toxicity in cowpea plant: Effect of foliar intervention of nano- $\mathrm{TiO}_{2}$ on tissue $\mathrm{Cd}$ bioaccumulation, stress enzymes and potential dietary health risk, Journal of Biotechnology, (2020).

27. MAHMUD, J., HASANUZZAMAN, M., NAHAR, K., RAHMAN, A., FUJITA, M. EDTA reduces cadmium toxicity in mustard (Brassica juncea L.) by enhancing metal chelation, antioxidant defense and glyoxalase systems, Acta Agrobot, 72 (2019) 1722.

28. JUKNYS, R., VITKAUSKAITĖ, G., RAČAITE், M., VENCLOVIENĖ, J. The impacts of heavy metals on oxidative stress and growth of spring barley, Open Life Sciences, 7 (2012) 299-306.

29. ZELINOVÁ, V., MISTRÍK, I., PAVLOVKİN, J., TAMÁS, L. Glutathione peroxidase expression and activity in barley root tip after short-term treatment with cadmium, hydrogen peroxide and t-butyl hydroperoxide, Protoplasma, 250 (2013) 1057-1065.

30. TAUlAVUORI, E., HELlSTRÖM, E.K., TAULAVUORI, K., LAINE, K. Comparison of two methods used to analyse lipid peroxidation from Vaccinium myrtillus (L.) during snow removal, reacclimation and cold acclimation, Journal of Experimental Botany, 52 (2001) 2375-2380.

31. CHAOUI, A., MAZHOUDI, S., GHORBAL, M.H., EL FERJANI, Cadmium and zinc induction of lipid peroxidation and effects on antioxidant enzyme activities in bean (Phaseolus vulgaris L.), Plant Science, 127 (1997) 139-147. 
32. DEY, S.K., DEY, J., PATRA, S., POTHAL, D. Changes in the antioxidative enzyme activities and lipid peroxidation in wheat seedlings exposed to cadmium and lead stress, Brazilian Journal of Plant Physiology, 19 (2007) 53-60.

33. ÇAKIR, S. Selenyum Toksisitesinin İki Arpa (Hordeum vulgare L.) Çeşitinde (TARM 92, BÜLBÜL 89) Antioksidan Enzim Aktivitesine Etkisi, in, Erciyes Üniversitesi, Fen Bilimleri Enstitüsü, 2007.

34. LI, Y., ZHANG, S., JIANG, W., LIU, D. Cadmium accumulation, activities of antioxidant enzymes, and malondialdehyde (MDA) content in Pistia stratiotes L, Environmental Science and Pollution Research, 20 (2013) 1117-1123.

35. VAJPAYEE, P., SHARMA, S., TRIPATHI, R., RAI, U., YUNUS, M. Bioaccumulation of chromium and toxicity to photosynthetic pigments, nitrate reductase activity and protein content of Nelumbo nucifera gaertin, Chemosphere, 39 (1999) 2159-2169.

36. TOPCUOĞLU, B., ONAL, M.K., ARI, N. Toprağa Uygulanan Kentsel Arıtma Çamurunun Domates Bitkisine Etkisi: I. Bitki Besinleri ve Ağır Metal İçerikleri, Mediterranean Agricultural Sciences, 16 (2003) 87-96.

37. KHAN, I., AHMAD, A., IQBAL, M. Modulation of antioxidant defence system for arsenic detoxification in Indian mustard, Ecotoxicology and Environmental Safety, 72 (2009) 626-634.

38. HARINASUT, P., POONSOPA, D., ROENGMONGKOL, K., CHAROENSATAPORN, R., Salinity effects on antioxidant enzymes in mulberry cultivar, Science Asia, 29 (2003) 109-113.

39. ATTIA, H., KARRAY, N., LACHAÂL, M. Light interacts with salt stress in regulating superoxide dismutase gene expression in Arabidopsis, Plant Science, 177 (2009) 161-167.

40. AYDIN, S., BUYUK, I., ARAS, E.S., Expression of SOD gene and evaluating its role in stress tolerance in $\mathrm{NaCl}$ and PEG stressed Lycopersicum esculentum, Turkish Journal of Botany, 38 (2014) 89-98.

41. ARAVIND, P., PRASAD, M.N.V. Zinc alleviates cadmium-induced oxidative stress in Ceratophyllum demersum L.: a free floating freshwater macrophyte, Plant Physiology and Biochemistry, 41 (2003) 391-397.

42. MISHRA, A., CHOUDHURI, M. Amelioration of lead and mercury effects on germination and rice seedling growth by antioxidants, Biologia Plantarum, 41 (1998) 469-473.

43. MATSUMURA, T., TABAYASHI, N., KAMAGATA, Y., SOUMA, C., SARUYAMA, H. Wheat catalase expressed in transgenic rice can improve tolerance against low temperature stress, Physiologia Plantarum, 116 (2002) 317-327.

44. GUPTA, S.D., AGARWAL, A., PRADHAN, S. Phytostimulatory effect of silver nanoparticles (AgNPs) on rice seedling growth: An insight from antioxidative enzyme activities and gene expression patterns, Ecotoxicology and Environmental Safety, 161 (2018) 624-633.

45. NAVABPOUR, S., YAMCHI, A., BAGHERIKIA, S., KAFI, H. Lead-induced oxidative stress and role of antioxidant defense in wheat (Triticum aestivum L.), Physiology and Molecular Biology of Plants, (2020) 1-10.

46. DUBE, B., SINHA, P., SHUKLA, K., CHATTERJEE, C., PANDEY, V.K., RAI, A.D., Involvement of excess cadmium on oxidative stress and other physiological parameters of eggplant, Journal of Plant Nutrition, 32 (2009) 996-1004.

47. MURZAEVA, S., Effect of heavy metals on wheat seedlings: activation of antioxidant enzymes, Applied Biochemistry and Microbiology, 40 (2004) 98-103.

48. SALEH, S.R., KANDEEL, M.M., GHAREEB, D., GHONEIM, T.M., TALHA, N.I., ALAOUISOSSÉ, B., ALEYA, L., ABDEL-DAIM, M.M. Wheat biological responses to stress caused by cadmium, nickel and lead, Science of The Total Environment, 706 (2020) 136013.

Manuscript received: 18.02 .2020 